\title{
Correction: phase 1 clinical trial of HER2-specific immunotherapy with concomitant HER2 kinase inhibtion
}

Erika Hamilton ${ }^{1}$, Kimberly Blackwell ${ }^{1}$, Amy C Hobeika ${ }^{2}$, Timothy M Clay ${ }^{3}$, Gloria Broadwater $^{4}$, Xiu-Rong Ren ${ }^{5}$, Wei Chen ${ }^{5}$, Henry Castro ${ }^{3}$, Frederic Lehmann ${ }^{3}$, Neil Spector ${ }^{1}$, Junping Wei ${ }^{6}$, Takuya Osada ${ }^{6}$, H Kim Lyerly $^{2}$ and Michael A Morse ${ }^{1 *}$

\section{Corrections}

In our original manuscript [1], the corresponding author, Michael A Morse, was missed from the authors' list. Therefore the correct author list should be:

Erika Hamilton, Kimberly Blackwell, Amy C Hobeika, Timothy M Clay, Gloria Broadwater, Xiu-Rong Ren, Wei Chen, Henry Castro, Frederic Lehmann, Neil Spector, Junping Wei, Takuya Osada, H Kim Lyerly and Michael A Morse.

Also the title of our original manuscript 'Phase 1 clinical trial of HER2-specific immunotherapy with concomitant HER2 kinase inhibtion' is also incorrect. The title should read:'Phase 1 clinical trial of HER2-specific immunotherapy with concomitant HER2 kinase inhibition'.

Journal of Translational Medicine regret any inconvenience that this inaccuracy might have caused.

\section{Competing interests}

The authors declare that they have no competing interests.

Authors' contribution

All authors read and approved the final manuscript.

\section{Author details}

'Department of Medicine, Division of Medical Oncology, Duke University Medical Center, Durham, NC, USA. ${ }^{2}$ Department of Surgery, Division of General Surgery, Duke University Medical Center, Durham, NC, USA. ${ }^{3}$ GlaxoSmithKline Biologicals, Rixensart, Belgium. ${ }^{4}$ Cancer Statistical Center, Duke Cancer Institute, Durham, NC, USA. ${ }^{5}$ Department of Medicine, Division of Gastroenterology, Duke University Medical Center, Durham, NC, USA. ${ }^{6}$ Department of Surgery, Division of Surgical Sciences, Duke University Medical Center, Durham, NC, USA.

Received: 26 March 2013 Accepted: 26 March 2013

Published: 27 March 2013

\section{Reference}

1. Hamilton, et al: Phase I clinical trial of HER2-specific immunotherapy with concomitant HER2 kinase inhibtion. J Trans/ Med 2012, 10:28.

\section{doi:10.1186/1479-5876-11-82}

Cite this article as: Hamilton et al: Correction: phase 1 clinical trial of HER2-specific immunotherapy with concomitant HER2 kinase inhibtion. Journal of Translational Medicine 2013 11:82.

\footnotetext{
* Correspondence: michael.morse@duke.edu

'Department of Medicine, Division of Medical Oncology, Duke University Medical Center, Durham, NC, USA

Full list of author information is available at the end of the article
}

\section{Submit your next manuscript to BioMed Central and take full advantage of: \\ - Convenient online submission \\ - Thorough peer review \\ - No space constraints or color figure charges \\ - Immediate publication on acceptance \\ - Inclusion in PubMed, CAS, Scopus and Google Scholar \\ - Research which is freely available for redistribution}

Submit your manuscript at www.biomedcentral.com/submit

C BioMed Central 